\title{
Monsanto branches out into fruits and vegetables
}

Monsanto recently acquired a US fruit and vegetable seed outfit, a move that both Wall Street analysts and environmental activists (oddly) agree could spell trouble. Indeed, these observers are concerned that the St. Louis, Missouri, biotech seed giant is once again overreaching, should the firm start producing genetically modified (GM) fruits and vegetables. The move could be an attempt to become the first company to step into that market and impose its products before competition from China, Brazil and India kicks in.

Last January, Monsanto announced its $\$ 1.4$ billion acquisition of Seminis, a fruit and vegetable seed company from Oxnard, California. Investors and environmentalists rarely agree on anything when it comes to Monsanto, but it seems that the Seminis deal-and on a smaller scale, the $\$ 300$ million purchase of the Emergent Genetics cotton seed company of Boulder, Colorado in February and the $\$ 40$ million acquisition of Lincoln, Nebraska-based grain seed firm NC+ Hybrids in March-has brought back bad memories of Monsanto's exuberant expansion in the late 1990s into the soy and seed corn business.

Both investors and environmentalists have been known to exaggerate and misjudge the larger meaning of news concerning Monsanto. The question is, did they overreact to the Seminis acquisition or is it with good reason that these two important Monsanto constituencies are apprehensive now? The answer is probably yes to both.

Wall Street was not entirely impressed by the Seminis deal because it is a bit too reminiscent of those done by former Monsanto CEO Robert Shapiro. Back in the late 1990s, Shapiro was accused by Wall Street of having indulged in overpriced acquisitions, even though they helped transform Monsanto from a sleepy chemical company into a global life science firm. As history seemingly repeats itself, some analysts believe Monsanto CEO Hugh Grant paid too much for Seminis. As an unprofitable company that lost $\$ 16$ million on 2004 sales of $\$ 525.8$ million, Seminis will need to prove its worth. Much like Shapiro, however, Grant justifies his far-flung purchases by saying that the acquisition was a long-term play whose true value will only reveal itself down the line.
Until now, Grant has been vague about his strategic intentions for Seminis except to say that he reckons the future is bright for those who produce the seeds for fruits and vegetables. After a decade of slow (and in some years, no) growth, in just the past two years, for example, sales of apples, oranges and bananas in the United States have started to recover, according to the US Department of Agriculture. Likewise, leading producers Brazil and the United States, and even niche producers such as New Zealand, have all reported robust growth in exports of both fruits and vegetables to the seemingly insatiable market that is China.

Despite the lack of open strategy, Grant has a point in noting that as is, Seminis seeds allow Monsanto to hedge its bets should its genetically modified (GM) business run into new snags down the way. Indeed, acquisituion costs and opposition to GM foods in Europe and Africa have contributed to an oppressive cost structure, stifling Monsanto's profits despite robust sales.

But the main reason environmentalists see shades of yesteryear in the Seminis deal is that the last time Monsanto started spending big on seeds, many of them were quickly re-engineered to include a new gene that made them impervious to Monsanto's topselling herbicide, Roundup (glyphosate). Environmental groups such as Greenpeace view the Seminis acquisition as a harbinger of new genetically engineered fruits and vegetables to come.

"I think that Monsanto would be very foolish to bring forward [GM] whole fruits or vegetables," says Lindsay Keenan, a GM campaigner for Greenpeace International in Amsterdam. "But, Monsanto can clearly benefit by having their patented genes in as many seeds as possible. The company is also quite capable of attempting to introduce [GM] fruit and vegetables in markets where it believes it can get away with it like the United States and Canada. Since GM papaya, for example, is only grown in Hawaii, but sold widely in the United States, they might assume that the [fruit] market is wide open."

There are, after all, still a large number of potentially lucrative fruits and vegetables that have not been commercially genetically engineered-strawberries, oranges, apples,

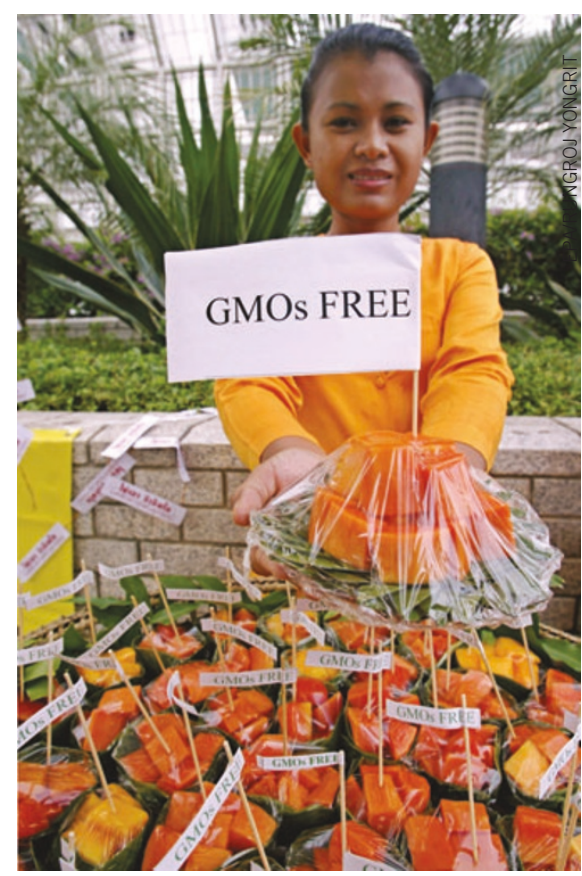

Opposition to genetically modified products, as demonstrated by these activists in Thailand, could gain momentum once GM fruits and vegetables reach the market.

and bananas, to name just a few. An industry insider who knows Monsanto says the company probably hasn't decided which fruits and vegetables it would focus on, but they agree that the company never would have bought Seminis if it had no intention of creating a GM fruit alternative.William Young, an analyst with Credit Suisse First Boston in New York concurs: "I think Monsanto wants to be an all purpose seed company and sees new varietals with improved traits as a way to gain market share in the fruit and vegetables market, which hasn't seen a lot of innovation or growth," he says. "But, there are a lot of political issues to resolve first." If history is any gauge, the political price and as a result, the economics of commercializing GM fruit will be higher than originally envisioned."

Stephan Herrera, New York

For more news and analysis go to news@nature.com www.nature.com/news 